Reprod. Nutr. Dévelop., 1985, 25 (1 A), 33-38.

\title{
In vitro steroid stimulation of final maturation in oocytes of rock bass (Amb/oplites rupestris) $\left({ }^{*}\right)$
}

\author{
F. W. GOETZ, F. CETTA
}

University of Notre-Dame, Department of Biology, Notre-Dame, Indiana, 46556, U.S.A.

Summary. The in vitro effects of various steroids on germinal vesicle break-down (GVBD) in oocytes of rock bass (Ambloplites rupestris) were investigated. Only oocytes in which the germinal vesicle was peripheral were responsive to steroids in vitro. Of the stimulatory steroids, $17 \alpha, 20 \beta$-dihydroxy-4-pregnen-3-one was the most effective, inducing GVBD at concentrations as low as $0.5-2.0 \mathrm{ng} / \mathrm{ml}$. The next most potent steroid was $20 \beta$-dihydroprogesterone, effective to concentrations of $7.8-16 \mathrm{ng} / \mathrm{ml}$. Progesterone, $17 \alpha, 20 \alpha$ dihydroxy-4-pregnen-3-one, 11-deoxycortisol and deoxycorticosterone were relatively less potent. The least effective steroids were 11-oxygenated corticosteroids and testosterone, inducing GVBD only at 1.0 or $2.0 \mu \mathrm{g} / \mathrm{ml}$. Estradiol $-17 \beta$ was completely ineffective at the concentrations tested. The specificity for steroid-stimulated GVBD in rock bass appears to be very similar to that observed in yellow perch (Perca flavescens), another perciform species. However, the stage during which rock bass oocytes are responsive to steroids appears to be different.

\section{Introduction.}

Investigations have shown that oocytes of teleost fish can be induced to undergo oocyte final maturation in vitro in the presence of steroids or gonadotropins (see Goetz, 1983, for review). In most fish species studied, progestational steroids are the most effective in inducing germinal vesicle breakdown (GVBD) in vitro and $17 \alpha, 20 \beta$-dihydroxy-4-pregnen-3-one $(17 \alpha, 20 \beta$ PG) is the most stimulatory (Goetz and Theofan, 1979 ; Duffey and Goetz, 1980 ; Jalabert 1976 ; Fostier et al., 1973 ; Nagahama et al., 1983). However, with the exception of investigations on yellow perch (Perca flavescens), nearly all in vitro investigations have been conducted on salmonid species or teleosts closely related to salmonids. Subsequent analyses of the hormone levels in blood during final maturation have also concentrated on salmonids (Goetz, 1983). Considering

(*) Contribution of the University of Notre-Dame Environmental Research Center. This material is based upon work supported by the National Science Foundation under Grant No. PCM-8214055. 
the very large number of perciform species, more attention should be given to these teleosts. To do so, we have begun to study several species of freshwater centrarchids. In this paper, we report that in vitro steroid stimulation of oocytes of the rock bass (Ambloplites rupestris-Centrarchidae-Perciformes) is very similar to that observed in the percid, yellow perch.

\section{Material and Methods.}

Mature female rock bass $(10-15 \mathrm{~cm})$ were collected during June from lakes at the University of Notre-Dame Environmental Research Center (UNDERC-Gogebic County, Michigan) using South Dakota Trapnets. Experimental fish were held outdoors at the Center in fiberglass tanks (284 or 1,134 I) supplied with continuously flowing water pumped from a neighboring lake. Holding temperatures were similar to those observed in lakes from which the rock bass were obtained (approx. $20^{\circ} \mathrm{C}$ ).

All in vitro experiments were conducted during June at the UNDERC laboratory. To determine the initial stage of oocyte maturation in vivo, rock bass ovaries were sampled with a glass catheter as previously described for yellow perch (Goetz and Theofan, 1979). To incubate ovaries in vitro, rock bass were killed and the ovaries removed and placed in Cortland medium modified with $0.025 \mathrm{M}$ Tris, $0.1 \mathrm{gm} / \mathrm{I} \mathrm{NaHCO}_{3}, 100 \mathrm{mg} / \mathrm{I}$ streptomycin sulfate and 100,000 IU/I penicillin. All other components of the medium were the same as previously described (Wolf and Quimby, 1969). The $\mathrm{pH}$ of the dissecting and incubation media was 7.8 and dissections were performed at room temperature. Small groups of intrafollicular oocytes containing 20-30 oocytes were dissected and incubated in $25 \mathrm{ml}$ Erlenmeyer flasks containing $5 \mathrm{ml}$ of the modified Cortland medium. Steroids were initially dissolved at high concentrations in $95 \%$ ethanol and appropriate aliquots $(1.0 \mu \mathrm{l}$ ethanol $/ 1.0 \mathrm{ml}$ medium $)$ added to the incubation medium to obtain the final steroid concentration. Incubation flasks were held in a constant temperature incubator at $22^{\circ} \mathrm{C}$ and periodically shaken throughout the incubation period. Following incubation, oocytes were assayed for GVBD in a fixative as previously described (Goetz and Bergman, 1978).

\section{Results.}

The sequence of final maturation in rock bass oocytes is very similar to that observed in yellow perch (Goetz, 1983). Initially, the many lipid droplets in the center of the oocyte begin to coalesce to form one or two large lipid droplets centrally located. As lipid droplet coalescence proceeds, the germinal vesicle (GV) remains slightly eccentric. Following coalescence the GV is usually located near the surface of the droplet, approximately half the distance from the center of the oocyte to the surface. Following this, the GV begins to migrate to the surface of the oocyte and there is a gradual increase in translucency. Once the GV reaches the surface it breaks down. At this time there is a dramatic increase in translucency and the lipid droplet assumes a peripheral position. 
Incubations were conducted on oocytes from females in various stages of GV migration. However, only oocytes in which the GV had migrated a significant distance towards the surface $1>4 / 5$ the distance from the center to the periphery) were responsive to steroid stimulation. Oocytes in which the GV was located directly on the oocyte surface were very responsive to steroid stimulation and did not undergo spontaneous GVBD following 24-36 hour incubations. Successful incubations were conducted on oocytes of 8 donor rock bass, however, results of only 4 representative assays are shown (figs. 1 and 2) for clarity.

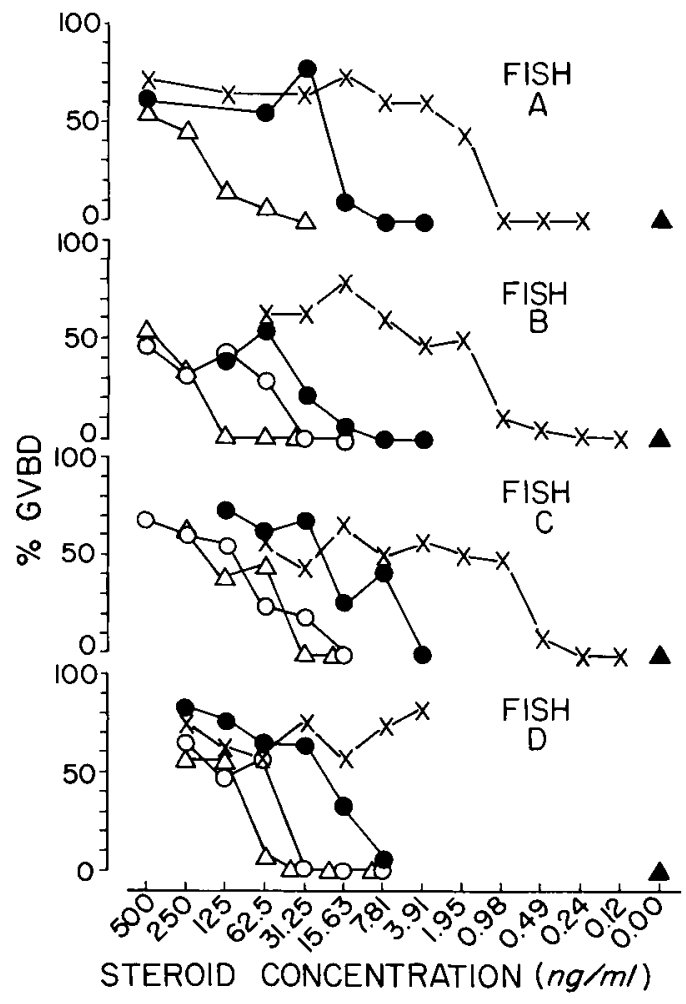

FIG. 1.

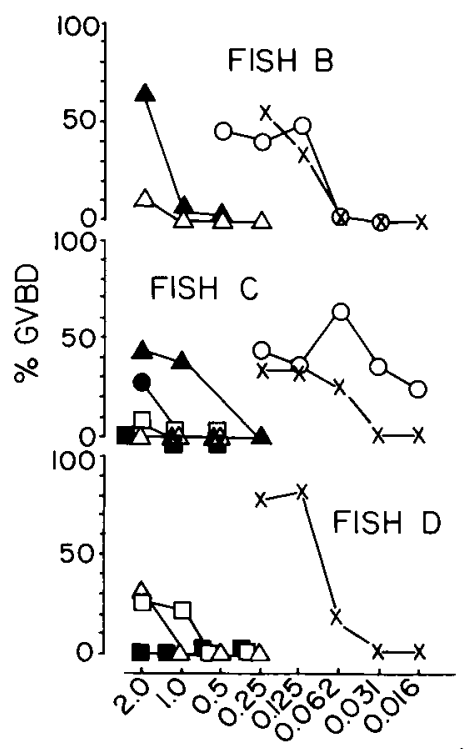

STEROID CONCENTRATION $(\mu g / \mathrm{m} /)$

FIG. 2 .

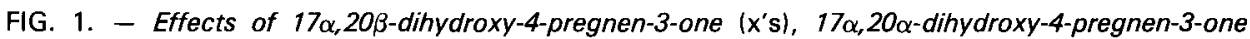
(open circles), 20 $\beta$-dihydroprogesterone (closed circles) and progesterone (open triangles) on germinal vesicle breakdown (GVBD) in rock bass oocytes taken from 4 females. Closed triangles indicate GVBD in controls without steroid. Prior to incubation, oocytes of donor $D$ were the most mature (GV touching surface of oocyte), donor $A$ and $B$ the least mature (GV 4/5 the distance from center to periphery) and donor $C$ intermediate. Donor $D$ oocytes assayed at $12 h$, donor $C$ at $24 \mathrm{~h}$ and donors $\mathrm{A}$ and $\mathrm{B}$ at $36 \mathrm{~h}$.

FIG. 2. - Effects of deoxycorticosterone (open circles), 11-deoxycortiso/ (x's), cortisol (closed circles), corticosterone (open triangles), 21-deoxycortisol (closed triangles), testosterone (open squares), and estradiol-17 $\beta$ (closed squares) on GVBD in rock bass oocytes from 3 females. Donors and control response as in figure 1. 
As noted in figures 1 and 2, incubations on different donors were conducted for varying lengths of time from 12-36 h. We observed a significant increase in oocyte mortality in incubates held longer than $36 \mathrm{~h}$ and in many cases there was even a noticeable increase in the number of dead oocytes in incubates from 12$36 \mathrm{~h}$. To optimize the number of viable eggs in incubations, oocytes that were initially further along (denoted by GV migration and clearing) prior to incubation, were also assayed earlier. Although this might have influenced the absolute amount of GVBD observed between incubations of various donor oocytes, most of the steroids were tested on oocytes of each donor and, therefore, a comparison of the potencies of each steroid could still be made within the results for each donor.

Of the various steroids tested, the most potent was always $17 \alpha, 20 \beta-P G$ (fig. 1). Depending on the initial stage of the oocyte prior to incubation, it was effective at concentrations as low as $0.5-2.0 \mathrm{ng} / \mathrm{ml}$ (fig. 1). The next most potent steroid was $20 \beta$-dihydroprogesterone, effective to concentrations of $7.8-16 \mathrm{ng} / \mathrm{ml}$ (fig. 1). Progesterone, 17 $\alpha, 20 \alpha$-dihydroxy-4-pregnen-3-one, 17 $\alpha$-hydroxyprogesterone (results not show), deoxycorticosterone and 11-deoxycortisol were relatively less stimulatory and were usually ineffective at concentrations below $31.0 \mathrm{ng} / \mathrm{ml}$ (figs. 1 and 2). Of the stimulatory steroids tested, the 11-oxygenated corticosteroids, cortisol, corticosterone, 21-deoxycortisol and the androgen, testosterone, were the least effective and usually induced GVBD only at concentrations of 1 or $2 \mu \mathrm{g} / \mathrm{ml}$ (fig. 2). In every incubation tested, estradiol-17 $\beta$ was totally ineffective in inducing GVBD at the concentrations tested $(2.0-0.25 \mu \mathrm{g} / \mathrm{ml}$ ) (fig. 2). A crude carp pituitary homogenate also induced $\sim 50 \%$ GVBD at concentrations from $0.5-0.125 \mathrm{mg} / \mathrm{ml}$ (results not shown).

Following 24-36 hours of incubation with steroids, ovulated oocytes were never observed in any incubates. A prominent space between the follicle and the oocyte was observed, however, in incubates of ovaries in which the oocytes contained GVs located directly on the periphery prior to incubation.

\section{Discussion.}

The results of the present study clearly demonstrate that steroids can induce GVBD in vitro in oocytes of the rock bass. Further, of the steroids tested, $17 \alpha$, $20 \beta$-PG was the most effective. Thus, these results follow closely those reported for salmonids (Jalabert, 1976 ; Fostier et al., 1973 ; Duffey and Goetz, 1980 ; Nagahama et al., 1983) and for the only other perciform species extensively studied, the yellow perch (Goetz and Theofan, 1979). In addition, the overall pattern in the specificity of steroid stimulation also follows closely that observed previously in trout, pike (Esox lucius), goldfish (Carassius auratus) and yellow perch (Jalabert, 1976 ; Fostier et al., 1973 ; Goetz and Bergman, 1978 ; Goetz, 1983). That is, 11-oxygenated corticosteroids are less effective than are 11deoxygenated corticosteroids. Also, as observed in various fish species, testosterone is relatively less effective and estrogens are totally ineffective (Goetz, 1983).

A major difference between the results of rock bass incubations and those of 
yellow perch incubations is in the sensitivity of the oocytes to steroid stimulation. In yellow perch oocytes, complete lipid droplet coalescence, migration of the GV from the center to the periphery and GVBD can be induced by steroids in vitro (Goetz and Theofan, 1979). In rock bass this was not possible. Only oocytes in which the GV was initially very close to the oocyte periphery were responsive to steroids in vitro. This phenomenon may be related to the difference in the overall temporal sequence of ovarian maturation between the two species. In perch, a significant degree of ovarian maturation has occurred in females by winter and, therefore, in the early spring oocytes are already mature several months prior to the natural spawning season (Malservisi and Magnin, 1969). In contrast, growth of the gonads in centrarchids is generally very rapid and does not occur until late spring when temperatures are rising (Kaya and Hasler, 1972). Extending this further, differences in sensitivity might also be related to the pattern of oocyte development observed in these species. Although both perch and rock bass have " group-synchronous » oocyte development (DeVlaming, 1983), there really is quite a difference in the appearance of the ovaries of these two species during the reproductive season. Perch ovaries contain one clutch of vitellogenic oocytes (of uniform diameter) whereas several clutches of developing oocytes can be observed in rock bass. As suggested (DeVlaming, 1983), there might be differences in the endocrine control mechanisms of final maturation in species exhibiting varying patterns of oocyte development.

Another noticeable difference between the results on rock bass and those on yellow perch was the absolute percentage of GVBD obtained with effective concentrations of maturational steroids. Although occasionally, 80-90 \% GVBD was observed, frequently the maximum percent was lower $(60-80 \%)$. In yellow perch incubations maximum GVBD is always much higher ( $>80 \%$ ) (Goetz and Theofan, 1979). In rock bass this was not related to the amount of maturational steroid present since even in the case of $17 \alpha, 20 \beta-P G$ the same relative amount of GVBD was observed over a wide concentration range (see fig. 1). Theoretically, longer incubation times might have resulted in a greater absolute amount of GVBD. For example, if the oocytes of Donor A had been incubated for 24 or 36 hours then, perhaps, a greater amount of GVBD might have been observed. However, in assaying the oocytes of all donors it was apparent that there were always some oocytes that did not even begin to respond regardless of the length of the incubation. This might be related to the dissection procedure that was necessary with rock bass ovaries. We have found with brook trout and yellow perch that ovaries can be extensively dissected prior to incubation so that small groups of intrafollicular oocytes are incubated. This ensures that all oocytes come in contact with the medium, possibly facilitating hormone stimulation. In contrast, we noted that ovaries of various centrarchids including rock bass would not withstand extensive dissection. Dissection of small groups containing 5-10 oocytes resulted in significant mortality, usually by 24 hours of incubation. This necessitated incubating single groups containing 20-30 oocytes. Of course this meant that some oocytes were nested inside the group and were not in direct contact with the medium. 
Résumé. Stimulation stérö̈dienne in vitro de la maturation terminale des ovocytes du Crapet de roche (Ambloplites rupestris).

L'effet de divers stéroïdes sur l'éclatement de la vésicule germinative des ovocytes du Crapet de roche (Ambloplites rupestris) a été étudié in vitro. Seuls les ovocytes présentant la vésicule germinative en position périphérique se sont montrés sensibles à certains stéroïdes in vitro. Parmi tous les stéroïdes stimulants, la $17 \alpha, 20 \beta$-dihydroxy-4-pregnen-3-one est le plus efficace, induisant l'éclatement de la vésicule germinative à des concentrations aussi faibles que 0,5 à $2,0 \mathrm{ng} / \mathrm{ml}$. Le plus actif est ensuite la $20 \beta$-dihydroprogestérone qui est efficace aux concentrations de 7,8 à $16 \mathrm{ng} / \mathrm{ml}$. La progestérone, la $17 \alpha, 20 \alpha$-dihydroxy-4pregnen-3-one, le 11-désoxycortisol et la désoxycorticostérone sont relativement moins actifs. Les stéroïdes les moins efficaces sont les 11-oxy-corticostéroïdes et la testostérone qui induisent un éclatement de la vésicule germinative à 1,0 ou $2,0 \mu \mathrm{g} / \mathrm{ml}$. L'œestradiol-17 $\beta$ est complètement inefficace aux concentrations employées. La spécificité d'action des stéroïdes sur l'éclatement de la vésicule germinative chez le Crapet de roche apparaît très semblable à celle observée chez la Perche canadienne (Perca flavescens), un autre perciforme. Cependant, les stades au cours desquels les ovocytes sont sensibles aux stéroïdes apparaissent différents.

\section{References}

DeVLAMING V., 1983. Oocyte development patterns and hormonal involvements among teleosts, 176-199. In RANKIN J. C., PITCHER T. J., DUGGAN R. T., Control processes in fish physiology, John Wiley \& Sons, New York.

DUFFEY R. J., GOETZ F. W., 1980. The in vitro effects of $17 \alpha$-hydroxy-20 $\beta$-dihydroprogesterone on germinal vesicle breakdown in brook trout (Salvelinus fontinalis) oocytes. Gen. comp. Endocrinol., 41, 503-565.

FOSTIER A., JALABERT B., TEROUI M., 1973. Action prédominante d'un dérivé hydroxylé de la progestérone sur la maturation in vitro des ovocytes de la Truite arc-en-ciel, Salmo gairdnerii. C. R. Acad. Sci. Paris, 277, 421-424.

GOETZ F. W., 1983. Hormonal control of oocyte final maturation and ovulation in fishes, 117-170. In HOAR W. S., RANDALL. D. J., DONALDSON E. M., Fish physiology, Vol. 9B, Acad. Press, New York, N. Y.

GOETZ F. W., BERGMAN H. L., 1978. The effects of steroids on final maturation and ovulation of oocytes from brook trout (Salvelinus fontinalis) and yellow perch (Perca flavescens). Biol. Reprod., 18, 293-298.

GOETZ F. W., THEOFAN G., 1979. In vitro stimulation of germinal vesicle breakdown and ovulation of yellow perch (Perca flavescens) oocytes. Effects of $17 \alpha$-hydroxy-20 $\beta$-dihydroprogesterone and prostaglandins. Gen. comp. Endocrinol., 37, 273-285.

JALABERT B., 1976. In vitro oocyte maturation and ovulation in rainbow trout (Salmo gairdneri), northern pike (Esox lucius) and goldfish (Carassius auratus). J. Fish. Res. Bd. Canad., 33, 974-988.

KAYA C. M., HASLER A. D., 1972. Photoperiod and temperature effects on gonads of green sunfish, Lepomis cyanellus (Rafinesque), during the quiescent, winter phase of its annual sexual cycle. Trans. am. Fish Soc., 101, 270-275.

MALSERVISI A., MAGNIN E., 1968. Changements cycliques annuels se produisant dans les ovaries de Perca fluviatilis flavescens (Mitchill) de la région de Montréal. Naturaliste Can., 95, 929-945.

NAGAHAMA Y., HIROSE K., YOUNG G., ADACHI S., SUZUKI K., TANAOKI B., 1983. Relative in vitro effectiveness of $17 \alpha, 20 \beta$-dihydroxy-4-pregnen-3-one and other pregnene derivatives on germinal vesicle breakdown in oocytes of four species of teleosts, ayu (Plecoglossus altivelis), amago salmon (Oncorhynchus rhodurus), rainbow trout (Salmo gairdneri) and goldfish (Carassius auratus). Gen. comp. Endocrinol., 51, 15-25.

WOLF K., QUIMBY M. C., 1969. Fish cell and tissue culture, 253-305. In HOAR W. S., RANDALL D. J., Fish physiology, Vol. 3, Acad. Press, New York, N. Y. 